\title{
Pengenalan Warna dan Bentuk Geometri Dengan Media Balok Pada Anak Usia 5-6 Tahun di TK Pertiwi 2 Jeron Nogosari Boyolali
}

\author{
Wahyuningsih \\ TK Pertiwi 2 Jeron Nogosari Boyolali \\ wabyuningsibummizafran@gmail.com
}

\begin{abstract}
This research is motivated by the results of the children's ability to recognize colors and geometric shapes in Kindergarten B has not developed as expected. This study aims to describe the planning, implementation and ability of children in recognizing colors and geometric shapes using blocks for children aged 5-6 years in TK Pertiwi 2 Jeron, Nogosari sub-district. The research method used is a descriptive method with a qualitative approach. (1) The planning of learning activities carried out by the teacher in the introduction of geometric shapes with block media for children aged 5-6 years at Kindergarten Pertiwi 2 Jeron Nogosari, namely lesson planning is adjusted to the existing curriculum and is made in the form of a Daily Learning Plan (RPPH). ) adapted to the theme of the day and adapted to the development of the child; (2) Implementation of learning the introduction of geometric shapes and colors using block media for children aged 5-6 years at TK Pertiwi 2 Jeron Nogosari, namely the steps taken by the teacher in accordance with the Daily Learning Implementation Plan (RPPH) for learning contained in (RPPH). ) made by classroom teachers that are tailored to the child's development; and (3) The ability to recognize geometric shapes and colors in children aged 5-6 years using blocks at Kindergarten Pertivi 2 Jeron Nogosari, which can be said to be developing according to expectations because all children can already recognize geometric shapes and colors as a whole. from the test results, the researcher recognizes the geometric shapes and colors.
\end{abstract}

Keywords: Color; Geometry; Media Block, Child

\begin{abstract}
ABSTRAK
Penelitian ini dilatarbelakangi dari hasil kemampuan anak untuk mengenal warna dan bentuk geometri di TK B belum berkembang sesuai harapan. Penelitian ini bertujuan untuk mendeskripsikan perencanaan, pelaksanaan dan kemampuan anak dalam pengenalan warna dan bentuk-bentuk geometri dengan media balok pada anak usia 5-6 tahun di TK Pertiwi 2 Jeron kecamatan Nogosari. Metode penelitian yang digunakan adalah metode deskriptif dengan pendekatan kualitatif. (1) Perencanaan kegiatan pembelajaran yang dilakukan guru dalam pengenalan bentuk-bentuk geometri dengan media balok pada anak usia 5-6 tahun di TK Pertiwi 2 Jeron Nogosari yaitu perencanaan pembelajaran disesuaikan dengan kurikulum yang telah ada dan dibuat dalam bentuk Rencangan Pelaksanaan Pembelajaran Harian ( RPPH ) yang disesuaikan dengan tema pada hari itu dan disesuaikan dengan perkembangan anak; (2) Pelaksanaan pembelajaran pengenalan bentuk-bentuk geometri dan warna dengan media balok pada anak usia 5-6 tahun di TK Pertiwi 2 Jeron Nogosari yaitu langkah-langkah yang dilakukan guru sesuai dengan Rencana Pelaksanaan Pembelajaran Harian ( RPPH) pembelajaran yang terdapat pada ( RPPH) yang dibuat oleh guru kelas yang disesuaikan dengan perkembangan anak; dan (3) Kemampuan mengenal bentuk-bentuk geometri dan warna pada anak usia 5-6 tahun dengan media balok di TK Pertiwi 2 Jeron Nogosari yaitu sudah dapat dikatakan berkembang sesuai harapan karena dari keseluruhan anak sudah dapat mengenal bentuk-bentuk geometri dan warna secara keseluruhan, dari hasil tes mengenal bentuk geometri dan warna yang telah dilakukan peneliti.
\end{abstract}

Kata Kunci: Warna; Geometri; Media Balok, Anak

Submitted May 02, 2021 | Revised May 19, 2021 | Accepted May 21, 2021

\section{Pendahuluan}

KBM (Kegiatan Belajar Mengajar) adalah suatu proses interaksi peserta didik dengan pendidik dan sumber belajar pada suatu lingkungan belajar (Darmuki dkk., 2017; Darmuki dkk., 2018; Darmuki dkk., 2019). KBM merupakan bantuan yang diberikan pendidik kepada peserta didik agar terjadi proses pemerolehan pengetahuan dan keterampilan, penguasaan kompetensi, serta pembentukan sikap dan kepercayaan diri pada peserta didik (Darmuki \& Hidayati, 2019; Darmuki \& Hariyadi, 2019). Hal ini sesuai dengan pernyataan Hidayati \& Darmuki (2021) yang mengemukakan bahwa KBM adalah suatu 
aktivitas yang dipersiapkan oleh pendidik untuk menarik dan memberi informasi kepada peserta didik, sehingga dengan persiapan yang dirancang oleh pendidik dapat membantu peserta didik dalam mencapai tujuan pembelajaran. Belajar adalah suatu proses yang dilakukan pendidik terhadap peserta didik sehingga terjadi perubahan tingkah laku baik dari aspek kognitif, afektif maupun psikomotorik akibat dari pengalaman (Darmuki, 2020). Belajar merupakan suatu proses perubahan tingkah laku yang membutuhkan dorongan atau motivasi untuk menggerakkan ke arah lebih baik, dari tidak bisa menjadi bisa, dari tidak tahu menjadi tahu (Darmuki dkk., 2017: 45). Perubahan tingkah laku tersebut bisa berupa dari aspek kognitif, afektif, maupun psikomotorik (Darmuki dkk., 2017: 76). Belajar juga dapat didefinisikan sebuah proses dimana tingkah laku ditimbulkan/berubah melalui latihan dan pengalaman (Hariyadi \& Darmuki, 2019: 282). Mengajar adalah menanamkan pengetahuan dan keterampilan pada peserta didik untuk mencapai tujuan yang telah ditetapkan (Darmuki \& Hidayati, 2019: 122). Tujuannya adalah penguasaan pengetahuan, keteterampilan dan pemahaman atau sikap oleh peserta didik.

Bermain merupakan kebutuhan bagi anak. Bermain pada anak usia dini merupakan suatu aktivitas fisik dan psikis yang harus dapat melibatkan panca indra, terutama pendengaran dan penglihatan, serta melibatkan otak (Chamidiyah, 2015; Pratiwi, 2017). Dalam pembelajaran geometri, guru harus mampu merancang permainan bagi anak agar mampu mengenal bentuk-bentuk geometri. Geometri menempati posisi khusus dalam kurikulum matematika, karena banyaknya konsep-konsep yang termuat di dalamnya. Dari sudut pandang psikologi, geometri merupakan penyajian abstraksi dari pengalaman visual dan spasial, misalnya bidang, pola, pengukuran dan pemetaan (Burger \& Shaughnessy, 1993). Namun berdasarkan pengamatan yang dilakukan di TK Pertiwi 2 Jeron Nogosari Boyolali, penulis melihat pada pembelajaran mengenal warna dan bentuk-bentuk geometri guru mengajak anak untuk menyebutkan warna dan bentuk-bentuk geometri sambil bernyanyi, guru menunjuk warna dan gambar bentuk-bentuk geometri di papan tulis yang dibuat guru danmengajak anak menyebutnya, setelah itu guru memberikan tugas kepada anak untuk membuat gambar bentukbentuk geometri dengan menyambungkan titik-titik di buku paketnya dan mewarnainya. Akan tetapi ada beberapa anak yang asik main sendiri, ada yang tidak mengerjakan tugasnya sampai selesai, bahkan anak menjadi cenderung lebih bosan.

Permasalahan tersebut tentu saja tidak dapat dibiarkan karena akan berdampak pada perkembangan anak serta diperlukan suatu solusi untuk menyelesaikan permasalahan pembelajaran tersebut. Salah satu solusi yang dapat digunakan adalah dengan menggunakan media pembelajaran. Beberapa penelitian terdahulu tentang pembelajaran mengenal warna dan bentuk geometri telah dilakukan diantaranya Penelitian Shobary, et al. (2014) dengan menggunakan Aplikasi Animasi Interaktif, penelitian Chusna \& Ningrum (2019) dengan mengebangkan Media Dakon Geometri, penelitian Aini, et al. (2020) dengan menggunakan Media Menara Geometri, dan penelitian Irsyadiansyah (2020) dengan perancangan meja dan kursi. Dari hasil penelitian-penelitian tersebut tampak penggunaan media sangat tepat dalam meningkatkan kemampuan anak dalam mengenal warna dan bentuk geometri. Pada penelitian ini penulis mengajarkan warna dan bentuk geometri kepada anak dengan menggunakan media balok. Pada pembelajaran dengan menggunakan media balok anak dikenalkan dengan berbagai bentuk geometri sepertisegitiga, persegi empat dan lingkaran. Pada saat bermain balok anak sangat senang memadukan berbagai macam bentuk balok menjadi sebuah bangunan yang anak inginkan.

Bermaindengan membangun balok-balok anak mendapatkan kesempatan melatih kerjasama mata dan tangan serta koordinasi fisik. Dengan balok warna anak juga bisa belajar macam macam warna. Selain itu anak juga belajar berbagai bentuk konsep matemtika melalui keseimbangan yang diperlukan dalam membangun gedung yang disusun. Melalui bermain anak akan mengenal balok yang sama, atau dua kali lebih panjang dari balok lain dan berbagai ukuran lain.

Menurut Clements, Wilson, \& Sarama (dalam Seefeldt \& Wasik , 2008:398) membangun konsep geometri pada anak dimulai dengan mengidentifikasi bentuk-bentuk, menyelidiki bangunan, 
memisahkan gambar- gambar biasa, seperti segiempat, lingkaran, segitiga. Pengenalan ketiga bentuk geometri tersebut dapat dimulai dengan memperlihatkan bentuk-bentuk secara langsung dan dapat juga dengan mengajak anak bermain sambil mengamati berbagai benda yang ada di sekelilingnya.

Perkembangan pemahaman konsep matematika menurut Bruner (Sriningsih, 2009: 35) dilakukan anak melalui tiga tahapan yaitu: (1)Tahap Enaktif. Anak secara langsung terlibat dalam memanipulasi objek; (2)Tahap Ikonik. Kegiatan yang dilakukan anak berhubungan dengan mental, yang merupakan gambaran dari objek-objek yang dimanipulasinya. Anak tidak langsung memanipulasi objek seperti pada tahap pertama (masa peralihan dari kongkrit ke abstrak); dan (3) Tahap Simbolik. Anak memanipulasi simbol-simbol atau lambang-lambang tertentu.

Van Hiele (dalam Suprihatiningsih, 2012) menyatakan bahwa terdapat lima tahapan perkembangan kognitif dalam memahami geometri yaitu: (1)Tahap pengenalan. Pada tahap ini anak baru mengenal bentuk-bentuk geometri seperti segitiga, segiempat dan lingkaran tanpa menyebutkan sifat-sifat dari bentuk geometri tersebut; (2)Tahap analisis. Pada tahap ini anak sudah dapat menyebutkan sifat-sifat dari bentuk-bentuk geometri seperti segitiga memiliki tiga sisi; (3) Tahap pengurutan. Pada tahap ini anak sudah mampu mengetahui hubungan keterkaitan antar bentuk geometri. Misalnya, anak sudah dapat mengurutkan bahwa persegi adalah persegi panjang. Persegi merupakan segiempat yang sisinya sama panjang; (4) Tahap deduksi. Pada tahap ini anak sudah mampu mengambil kesimpulan secara deduksi yaitu dari hal-hal yang umum ke khusus. Pada tahap ini anak dapat membuktikan bahwa apabila segiempat dilipat menjadi dua maka akan membentuk dua segitiga ataupun dua segiempat; dan (5) Tahap akurasi/keakuratan. Pada tahap ini anak sudah memahami betapa pentingnya ketepatan dari prinsip-prinsip dasar yang melandasi suatu pembuktian. Tahap keakuratan merupakan tahap berpikir yang tinggi, rumit, dan kompleks dalam memahami konsep geometri. Oleh karena itu pada anak usia dini masih belum sampai pada tahap berpikir ini.

Menurut Bird (dalam Qudsiah, 2013: 8) bentuk geometri meliputi: (1) Segitiga adalah suatu bidang yang dibentuk oleh tiga garis lurus. Jumlah ketiga sudut segitiga sama dengan 180; (2) Lingkaran adalah suatu bidang sederhana yang dibatasi oleh suatu garis melingkar, setiap titik terletak pada garis tersebut memiliki jarak yang sama terhadap satu titik ditengah lingkaranl (3)Setengah Lingkaran adalah setengah dari satu lingkaran penuh; (4)Segiempat adalah persegipanjang yang keempat sisinya sama panjang: dan (5) Persegi panjang adalah segiempat dengan sisi yang sejajar dan sama panjang, serta keempat sudutnya siku-siku.

Balok sangat ideal bagi anak untuk melakukan permainan dramatis. Balok dapat memberikan kegiatan belajar yang sehat yang memungkinkan anak memahami konsep-konsep yang dibutuhkan dalam matematika, ilmu pengetahuan, geometri, studi social, dan banyak lagi (Asmawati, 2008: 11.4). Chidren Resources Internasional (CRI) (dalam Wahyuni, 2013: 11) dijelaskan bahwa media balok adalah alat edukatif yang terbuat dari kayu atau plastik berbentuk balok dengan bentuk-bentuk yang beragam, dan kegiatan pembelajaran ini terdiri dari menyusun, merangkai dan membangun.

Balok satuan dibuat dalam bentuk yang proporsional dan memungkinkan anak untuk belajar konsep matematika ketika memainkannya. Ukuran dasar balok ini adalah $5 \frac{1}{2}$ inci x $23 / 4$ inci $3 / 8$ inci. Semua balok panjangnya dan lebarnya proporsional terhadap ukuran dasar balok. Semakin banyak bentuk dan ukuran balok yang kita sediakan, anak akan semakin kreatif. (Asmawati, 2008: 11.10).

Bermain dengan membangun balok-balok anak mendapatkan kesempatan melatih kerja sama mata dan tangan serta koordinasi fisik. Selain itu anak belajar berbagai bentuk konsep matematika melalui keseimbangan yang diperlukan dalammembangun gedung yang disusun. Melalui bermain anak akan mengenal balok yang sama, atau dua kali lebih panjang dari balok lain dan berbagai ukuran lain (Kanaria, 2011:12)

Pendapat Saleh Dan Wismiarti (2010: 38) manfaat bermain balok akan memberikan kesempatan bagi anak untuk mengembangkan: (1) Keterampilan interaksi dengan teman sebaya; (2) Kemampuan berkomunikasi; (3) Kekuatan dankoordinasi gerakan motorik halus dan kasar; (4) Pemikiran simbolik; 
(5) Konsep matematika dan geometri; (6) Pengetahuan topologi/pemetaan; dan (7) Keterampilan membedakan penglihatan.

Kemudian fungsi dari bermain balok (dalam Kanaria, 2011: 14) yaitu belajar mengenai konsep; dalam bermain susun balok, akan ditemukan beragam konsep, seperti warna, bentuk, ukuran, dan keseimbangan. Belajar mengembangkan imajinasi : untuk membangun sesuatu tentunya diperlukan kemampuan anak dalam berimajinasi. Imajinasi yang dituangkan dalam karya mengasah kreativitas anak dalam mencipta berbagai bentuk. Melatih kesabaran: dalam menyusun balok satu demi satu agar terbentuk bengunan seperti dalam imajinasinya, tentu anak memerlukan kesabaran. Berarti ia melatih dirinya sendiri untuk melakukan proses dari awal sampai akhir demi mencapai sesuatu. Ia berlatih untuk menyelesaikan pekerjaannya. Secara social anak belajar berbagi: ketika bermain susun balok bersama teman, anak terlatih untuk berbagi. Misalnya,jika si teman kekurangan balok tertentu, anak diminta untuk maun berbagi balok yang dibutuhkan. Perlahan tapi pasti, anak juga belajar untuk tidak saling berebut saat bermain. Mengembangkan rasa percaya diri anak: ketika anak bermain susun balok dan bisa membuat bangunan, tentu anak akan merasa puas dan gembira. Pencapaian ini akan menumbuhkan rasa percya diri akan kemampuannya.

Langkah-langkah dalam bermain balok menurut Arifin (2009: 82) dilakukan dengan urutan menata pijakan bermain balok yang terdiri dari: Pijakan lingkungan, seperti merencanakan densitas dan intensitas yang memenuhi 3 jenis main, menyediakan alas untuk bermain, menyiapkan sejumlah balok unit darikayu berwarna natural, menyiapkan sejumlah aksesoris. Pijakan sebelum main, seperti duduk melingkar, membacakan gambar bangunan, berdialog tentang konsep bangunan "rumah", "mesjid", "kantor", dll. Menunjukkan detail bangunan, menyebutkan macam bentuk balok, membuat kesepakatan aturan main, memberi nama anak pada masing-masing alas, dan mempersilahkan anak mengambil balok untuk bermain pembangunan. Pijakan saat main, dilakukan guru guna memberi penguatan pada karya anak, dilakukan observasi karya tanpa intervensi, memperkuat dengan pemberian aksesoris, semua kegitan dan karya anak didokumentasikan, diingatkan batas waktu main, disepakati hasil karya anak terakhir, dan beres-beres. Dan pijakan sesudah main, guru/pendidik bersama anak duduk membentuk lingkaran, setiap anak diminta mengingat kembali pengalaman mainnya, memberikan dukungan dan motivai, disampaikan harapan bermain yang akan datang.

Ada empat tahapan perkembangan anak dalam bermain balok menurut Asmawati (2008: 11.1411.15) yaitu: Tahap 1 : Membawa balok (bermain fungsional) anak yang belum pernah bermain dengan balok sebelumnya, akan membawa balok berkeliling atau memuatnya ke dalam truk (mainan) dan membawanya. Pada saat itu, anak tertarik untuk belajar tentang balok-seberapa berat balok-balok tersebut, seperti apa rasanya, dan seberapa banyak balok-balok dapat dibawa sekali angkat. Dengan mengalami hal-hal tersebut, anak mulai belajar tentang balok-balok yang dapat digunakannya dan memiliki pemahaman tentang apa yang dapat dan apa yang tidak dapat ia lakukan dengan balok. Tahap 2: Menumpuk balok dan meletakkannya di lantai. Menumpuk atau mengaturbalok di lantai adalah tahap berikutnya. Pada tahap 2 anak masih meneruskan bermain tentang sifat-sifat balok. Mereka menemukan bagaimana caranya membuat menara dengan menumpuk balok dan bagaimana keliatannya jika disusun di lantai. Pada tahap ini anak juga menerapkan khayalan dan kemampuan berpikir kritis. Bagi pemula, balok berpermukaan rata di lantai biasanya dibuat menjadi jalan. Tahap 3: Menghubungkan balok untuk membentuk bangunan. Penggunaan jalan pada tahap 2 menandai transisi dari hanya menumpuk balok, kepada membuat bangunan yang nyata. Anak yang telah terbiasa dengan bangunan jalan menemukan bahwa mereka dapat menggunakan jalan untuk menghubungkan menaramenara. Penemuan ini membawa anak kepada tahap percobaan aktif ketika anak menerapkan kemampuan memecahkan masalah. Biasanya dalam tahap 3 anak telah memiliki berbagai pengalaman dengan balok. Pengalaman ini membuat mereka mampu menggunakan balok dengan cara-cara baru yang kreatif. Dan tahap 4: Membuat bangunan yang jelas terlihat (bermain dramatik). Anak yang berpengalaman dengan balok dapat meletakkan balok dengan menggunakan keterampilan dan 
ketelitian. Anak belajar beradaptasi pada bangunan mereka dengan membuat struktur dan dengan membangun balok ke atas, ke sekeliling atau di atas penghalang. Pada tahap 4 anak mulai ahli dalam membuat susunan yang kompleks dan tidak mencontoh karya orang lain (asli buatan sendiri)

Kemudian ada tahap-tahap perkembangan pembangunan balok anak (Gutama, 2004: 10) yaitu: Menggunakan Balok Tanpa Membuat Bangunan. Tahap 1: Tanpa Bangunan. Bangunan-Bangunan Garis Lurus. Tahap 2: Susunan Garis Lurus ke Atas. Tahap 3: Susunan Garis Lurus ke Samping. Daerah Bangunan Dua Dimensi. Tahap 4: Susunan Daerah Lurus ke Atas. Tahap 5: Susunan Daerah Mendatar. Bangunan Tiga Dimensi. Tahap 6: Ruang Tutup ke Atas. Tahap 7: Ruang Tutup Mendatar. Tahap 8: Menggunakan Balok untuk Membangun Bangunan Tiga Dimensi yang Padat. Tahap 9: Ruang Tutup Tiga Dimensi. Tahap 10: Menggabungkan/Mengkombinasikan Beberapa Bentuk Bangunan. Permainan Representasi. Tahap 11: Mulai Memberi Nama. Tahap 12: Satu Bangunan, Satu Nama. Tahap 13: "Bentuk-bentuk" Balok diberi Nama.Tahap 14: Memberi Nama Objek-objek yang Terpisah. Tahap 15: Merepresentasikan Ruang Dalam. Tahap 16: Obyek-obyek di dalam Ditempatkan di Luar. Tahap 17: Representasi Ruang Dalam \& Ruang Luar Secara Tepat. Tahap 18: Bangunan Dibangun Sesuai Skala.dan tahap 19: Bangunan Yang Terdiri Dari Banyak Bagian.

Bermain balok bagi anak mempunyai manfaat yang tidak sedikit. Beberapa aspek kemampuan pada anak dapat tumbuh dengan baik jika orang tua atau guru secara maksimal membimbing dan mengarahkan. Berikut manfaat dari bermain balok antara lain: (1) Dari aspek bahasa dapat menumbuhkan kemampuan anak dalam berbicara dan mengolah vokal. Ayah Bunda hendaknya aktif bertanya atau memberi pancingan agar anak mengungkapkan ide-ide dalam bermain balok. Melakukan diskusi kecil, tanya jawab langsung saat bermain balok apalagi jika dilakukan dengan bersama temanteman akan memancing komunikasi; (2) Aspek sosial emosional, rasa percaya diri akan tumbuh dengan sendirinya. Anak akan mengalami kepuasan dengan hasil karya dan imajinasi sendiri. Mencoba dan terus mencoba walaupun sesekali mengalami kegagalan tidak akan menghalangi keinginanya untuk belajar. Perkembangan sosial anak juga akan tumbuh dengan saling berinteraksi dan bertukar ide dalam kerjasama menyusun balok; (3)Aspek perkembangan fisik, hal ini berhubungan dengan motoric halus anak. Jari-jari dan otot tangannya akan semakin kuat dan hal ini akan membantu kemampuan anak dalam memegang pensil dan menulis; (4)Perkembangan kreativitas, hal ini disebabkan dalam bermain balok anak diberikan kesempatan untuk menggunakan ide d4an pikiran secara kreatif. Ajukan pertanyaan dan arahkan anak dalam berbagai bentuk dalam permainan balok; (5)Aspek perkembangan kognitif, upayakan dengan menggali pemahaman anak dalam memecahkan suatu masalah. Misal, saat membuat jalan raya tidak harus lurus, namun dapat menggunakan balok yang berbentuk lengkung.

Dalam mendampingi anak bermain balok yang paling penting Ayah Bunda dan guru harus bersikap sabar dan memberikan energi positif agar anak dapat mengembangkan kemampuan sesuai dengan usia dan perkembangannya. Pujian dan hadiah dapat Ayah Bunda dan guru agar anak merasa dihargai dalam berkreasi bermain balok. Namun berdasarkan pengamatan sementara (observasi) yang peneliti lakukan di TK Pertiwi 2 Jeron Nogosari, peneliti melihat pada pembelajaran mengenal bentukbentuk geometri guru mengajak anak untuk menyebutkan bentuk-bentuk geometri dan warna sambil bernyanyi, guru menunjuk gambar bentuk-bentuk geometri di papan tulis yang dibuat guru dan mengajak anak menyebutnya, setelah itu guru memberikan tugas kepada anak untuk membuat gambar bentuk-bentuk geometri dengan menyambungkan titik-titik di buku paketnya dan mewarnainya. Akan tetapi ada beberapa anak yang asik main sendiri, ada yang tidak mengerjakan tugasnya sampai selesai, bahkan anak menjadi cenderung lebih bosan. Selain itu untuk mengajarkan bentuk geometri kepada anak guru juga menggunakan media balok. Pada saat pembelajaran dengan menggunakan media balok anak dikenalkan dengan berbagai bentuk geometri dan berbagai warna yang tertera di balok seperti segitiga berwarna hijau, persegi empat berwarna merah dan lingkaran berwarna kuning dan masih banyak balok warna lainnya. Pada saat bermain balok anak sangat senang memadukan berbagai macam bentuk balok menjadi sebuah bangunan yang anak inginkan sesuai warna yang mereka sukai. 
Berdasarkan uraian di atas penulis ingin mengetahui lebih jauh mengenai proses pembelajaran mengenal bentuk-bentuk geometri dan warna, khususnya pada penggunaan media balok dalam mengenalkan bentuk-bentuk geometri dan warna pada anak usia 5-6 tahun di TK Pertiwi 2 Jeron Nogosari.

\section{Metode Penelitian}

Subjek penelitian ini pada anak 5-6 tahun di TK Pertiwi 2 Jeron Nogosari. Metode yang digunakan peneliti dalam penelitian ini adalah metode deskriptif yaitu prosedur pemecahan masalah yang diselidiki dengan mengambarkan atau menjelaskan secara apa adanya tentang keadaan subjek atau objek penelitian. Dengan alasan bahwa permasalahan yang diteliti adalah peristiwa yang sedang terjadi berdasarkan fakta yang tampak atau sebagaimana adanya. Pendekatan yang digunakan peneliti dalam penelitian ini yaitu dengan pendekatan kualitatif, Menurut Sugiyono (2010:1), "Metode penelitian kualitatif adalah metode penelitian yang digunakan untuk meneliti pada kondisi obyek yang alamiah, (sebagai lawannya adalah eksperimen) dimana peneliti adalah sebagai instrumen kunci, teknik pengumpulan data dilakukan secara trianggulasi (gabungan), analisis data bersifat induktif, dan hasil penelitian kualitatif lebih menekankan makna dari pada genaralisasi". Hal ini disebabkan karena peneliti ingin mendeskripsikan secara jelas dan rinci tentang pengenalan bentuk-bentuk geometri dengan media balok serta mendapatkan data yang mendalam mengenai data yang menjadi fokus penelitian. Penelitian ini menggunakan pendekatan kualitatif karena data yang dikumpulkan berupa kata-kata, gambar, bukan angka-angka. Dalam penelitian ini, data dimaksudkan sebagai hasil yang diperoleh selama penelitian berlangsung yang kemudian diolah menjadi hasil akhir dalam penelitian. Adapun data dalam penelitian ini adalah data yang berasal dari sumber primer dan sekunder.

Menurut Sugiyono (2008:308) "Sumber primer adalah sumber data yang langsung memberikan data kepada pengumpul data, dan sumber sekunder merupakan sumber yang tidak langsung memberikan data kepada pengumpul data, misalnya lewat orang lain atau lewat dokumen". Data primer diperoleh berdasarkan hasil wawancara peneliti dengan sumber data (guru yang menjadi sumber data), dan hasil observasi peneliti di lapangan. Selain itu data sekunder yang peneliti dapatkan berdasarkan arsip- arsip dan dokumen-dokumen yang berasal dari tata sekolah. Proses analisis data selama di lapangan model Miles dan Huberman(Sugiyono, 2011:338-345) yaitu terdiri dari : Data atau informasi yang berhasil dikumpulkan dari proses penelitian biasanya berupa narasi yang jumlahnya bisa ratusan halaman. Agar informasi "bahan mentah" ini tidak membingungkan peneliti maka perlu uraian atau laporan terinci dalam tahap selanjutnya yaitu reduksi data. Merupakan proses berfikir sensitif yaitu merangkum, memilih hal-hal pokok. Memfokuskan pada hal-hal yang penting, dicari tema dan polanya dan membuang yang tidak perlu.

Dalam penelitian ini, akan dilakukan pemeriksaan kembali data-data yang sudah terkumpul baik dari hasil observasi, hasil wawancara, catatan lapangan, dokumen dan daftar cek. Data-data yang telah dikumpulkan akan direduksi untuk memberikan gambaran yang lebih jelas mengenai hasil penelitian yang dilakukan. Aspek yang peneliti reduksi adalah yang berkaitan dengan faktor-faktor penyebab anak menjadi tidak mandiri pada usia 5-6 tahun di TK Pertiwi 2 Jeron Nogosari. Dalam penelitian kualitatif, penyajian data dimaksudkan untuk menyusun segala informasi yang diperoleh agar mempermudah penelitimenganalisis data-data yang sudah dikumpulkan. Dalam penelitian ini, penyajian data dapat dilakukan dalam bentuk tabel, grafik, phie chard, pigtogram dan sejenisnya. Melalui penyajian data tersebut maka data akan dapat terorganisasi, tersusun dalam pola hubungan sehingga akan mudah dipahami. Tetapi yang paling sering digunakan dalam menyajikan data yaitu dengan teks bersifat naratif.

\section{Hasil dan Pembahasan}


Penelitian ini dilaksanakan di TK Pertiwi 2 Jeron Nogosari yang beralamat di Jalan kaliyososimo, dukuh purworejo Rt 04 Rw 06, Desa Jeron, kecamatan Nogosari, kabupaten Boyolali. Peneliti mengadakan wawancara dengan guru, menyusun pedoman observasi berupa check list, dokumentasi dan catatan lapangan. Dari hasil wawancara dan observasi yang dilakukan peneliti dapat disimpulkan bahwa perencanaan pembelajaran pengenalan bentuk-bentuk geometri pada anak yaitu pembuatan rencanaan kegiatan pembelajaran guru menggunakan PERMEN No. 58 Tahun 2009 sebagai acuan dan menyesuaikan dengan kurikulum yang dibuat sekolah. Pengguanaan media balok pada saat menyampaikan apersepsi guru hanya menggunakan pada tema yang ada hubungannya, seperti pengenalan bentuk geometri. Jika tidak ada guru menggunakan buku paket yang sesuai dengan tema atau menggunakan whiteboard dan spidol. Seharusnya guru harus lebih kreatif dalam penyampaian apersepsi sesuai dengan tema, walaupun tidak tersedianya media yang dapat mewakili.

Pada pelaksanaan pembelajaran pengenalan bentuk-bentuk geometri pada anak melalui bermain balok yaitu langkah-langkah yang dilakukan guru sesuai dengan perencanaan pembelajaran yang terdapat pada RPPH yang dibuat oleh guru kelas dan disesuaikan dengan perkembangan anak. Hanya saja guru kurang berpartisipasi pada saat anak bermain balok. Padahal terdapat juga media lain yang dapat mendukung pada saat anak bermain balok. Yaitu aksesoris berbentuk manusia, pohon, mobil maupun motor. Pada alokasi bermain balok sangat kurang, karena waktu yang disediakan hanya 45 menit, sedangkan dalam bermain balok dibutuhkan waktu kesempatan sama anak yaitu 60 menit.

Kemampuan anak mengenal bentuk-bentuk geometri melalui bermain balok sudah dapat dikatakan berkembang sesuai harapan karena dari keseluruhan anak sudah dapat mengenal bentukbentuk geometri, dari hasil tes mengenal bentuk geometri yang telah dilakukan penulis. Namun ada dua anak yang masih belum mengenal bentuk geometri secara keseluruhan, disebabkan karena kurangnya fokus anak pada saat guru menyampaikan pembelajaran mengenalkan bentuk-bentuk geometri.

Perencanaan kegiatan pembelajaran yang dilakukan dalam mengenal bentuk-bentuk geometri yaitu dengan membuat pola, menyebutkan pola, melipat, menggunting, menempel, kemudian menghubungkan titik-titik, maupun menyusun bentuk-bentuk geometri sesuai bentuk. Dan yang pastinya perencanaan pembelajaran disesuaikan dengan kurikulum yang telah ada dan dibuat dalam bentuk Rencana Pelaksanaan Pembelajaran Harian ( RPPH ) yang disesuaikan dengan tema pada hari itu dan disesuaikan dengan perkembangan anak.

Perencanaan pembelajaran adalah rencana yang dibuat oleh guru untuk memproyeksikan kegiatan apa yang akan dilakukan oleh guru dan anak agar tujuan dapat tercapai (Masitoh, et al., 2005). Perencanaan pembelajaran mengandung komponen-komponen yang ditata secara sistematis dimana komponen-komponen tersebut saling berhubungan dan salingketergantungan satu sama lain. Kemudian adanya bahan main yang digunakan pada saat pembelajaran mengenal bentuk-bentuk geometri yaitu kertas origami, buku paket dan pensil atau crayon, serta media balok. Media balok tersebut dapat membantu anak lebihmudah mengenal bentuk geometri secara langsung, karena anak langsung melihat bahkan dapat meraba bentuk geometri yang terdapat pada permukaan balok.

Selanjutnya dalam pelaksanaan pembelajaran pengenalan bentuk-bentuk geometri pada anak melalui bermain balok yaitu langkah-langkah yangdilakukan guru dimulai pada mengenalkan bentukbentuk dasar geometri yaitu pada permukaan balok, meminta anak mengelompokkan bentuk balok, kemudian meminta anak membuat bangunan dari berbagai bentuk balok (sesuai keinginan anak). Kegiatan tersebut merupakan salah satu perencanaan pembelajaran yang terdapat pada RPPH yang dibuat oleh guru kelas.

Media balok yang digunakan pada saat pembelajaran pengenalan bentuk-bentuk geometripun merupakan balok yang standar, karena dengan balok yang standar diharapkan kemampuan anak dapat berkembang sesuai harapan. Dalam pengenalan bentuk-bentuk geometri sebagian besar hampir mencakup semua balok yang ada, karena dari tiap balok memiliki bentuk dasar berbentuk geometri. 
Kemudian pada saat mengenalkan bentuk-bentuk geometri melalui media balok mengalami kesulitan yaitu pada saat menyatukan persepsi bentuk suatu balok, karena dari keseluruhan bentuk balok tersebut terdapat kemiripan bentuk dengan bentuk lainnya. Dan usaha yang dilakukan guru untuk mengatasi kesulitan dalam mengenalkan bentuk-bentuk geometri melalui media balok yaitu dengan cara membandingkan bentuknya dengan bentuk balok yang sudah anak ketahui agar anak dapat mengetahui perbedaan dari bentuk balok-balok tersebut. Pada alokasi bermain balok sangat kurang, karena waktu yang disediakan hanya 45 menit, sedangkan dalam bermain balok dibutuhkan waktu kesempatan sama anak yaitu 60 menit.

Pada saat pembelajaran guru menggunakan media balok dalam mengenalkan bentuk-bentuk geometri respon anak sangat antusias dan senang sekali. Anak juga dapat melihat dan meraba langsung bentuk geometri yang disebutkan dan dijelaskan oleh guru, dan kemampuan anak mengenal bentuk geometri sudah dapat dikatakan berkembang sesuai harapan karena dari keseluruhan anak sudah dapat mengenal bentuk-bentuk geometri secara keseluruhan, dari hasil tes mengenal bentuk geometri yang telah dilakukan penulis. Karena dengan media balok anak dapat langsung melihat bentuk asli dari bentuk geometri yang dikenalkan kepada anak.Hanya ada dua anak yang masih belum mengenal bentuk geometri secara kaseluruh, karena anak kurang fokus saat guru melakukan pembelajaran mengenalkan bentuk-bentuk geometri.

\section{Kesimpulan}

Berdasarkan hasil penelitian dan pembahasan yang telah dilakukan oleh peneliti mengenai pengenalan bentuk-bentuk geometri dengan media balok padaanak usia 5-6 tahun di TK Pertiwi 2 Jeron Nogosari maka dapat diambil kesimpulan bahwa Media balok dapat membantu anak lebih mudah mengenal bentuk geometri dan warna secara langsung, karena anak langsung melihat bahkan dapat meraba bentuk geometri yang terdapat pada permukaan balok. Kemampuan mengenal bentukbentuk geometri dan warna pada anak usia 5-6 tahun dengan media balok di TK Pertiwi 2 Jeron Nogosari yaitu sudah dapat dikatakan berkembang sesuai harapan karena dari keseluruhan anak sudah dapat mengenal bentuk-bentuk geometri dan warna secara keseluruhan, dari hasil tes mengenal bentuk geometri dan warna yang telah dilakukan peneliti.

\section{Daftar Pustaka}

Aini, A. N., Jayanti, D. D., \& Luthfillah, M. (2020). Pengaruh Penggunaan Media Menara Geometri Dalam Meningkatkan Kemampuan Mengenal Warna Dan Bentuk Geometri Anak Usia Dini. Sawabiq: Jurnal Keislaman, 1(01).

Asmawati, Luluk. (2008). Pengelolaan Kegiatan Pengembangan Anak Usia Dini. Jakarta: Universitas Terbuka.

Chamidiyah, C. (2015). Pembelajaran melalui Brain Based Learning Dalam Pendidikan anak usia Dini. Edukasia: Jurnal Penelitian Pendidikan Islam, 10(2).

Chusna, L. A., \& Ningrum, M. A. (2019). Pengembangan Media Dakon Geometri Untuk Meningkatkan Kemampuan Mengenal Bentuk Geometri Anak Usia 4-5 Tahun. PAUD Teratai, $8(2)$.

Darmuki, Agus. (2020). Upaya Meningkatkan Kemampuan Berbicara Mahasiswa Menggunakan Media Aplikasi Google Meet Berbasis Unggah Tugas Video Di Youtube Pada Masa Pandemi Covid-19. Jurnal Educatio FKIP UNMA, Vol 6(2),655-661.

Darmuki, A. \& Ahmad Hariyadi. (2019). Eksperimentasi Model Pembelajaran Jucama Ditinjau Dari Gaya Belajar Terhadap Prestasi Belajar Mahasiswa Mata Kuliah Berbicara Di Prodi PBSI IKIP PGRI Bojonegoro. Kredo. 3(1), 62-72.

Darmuki, A. \& Hidayati N.A. (2019). An Investigation of The Cooperative Learning Using Audio Visual Media in Speaking Skill Subject. ICSTI. 121-126. 
Darmuki, A. \& Hidayati, N.A. (2019). Peningkatan Kemampuan Berbicara Menggunakan Metode Kooperatif Tipe NHT pada Mahasiswa Tingkat I-A Prodi PBSI IKIP PGRI Bojonegoro Tahun Akademik 2018/2019. Jurnal Pendidikan Edutama. Vol. 6(2), hlm 9-18.

Darmuki, A., Andayani, Joko Nurkamto, Kundharu Saddhono. (2017). Cooperative, Synectics, and CTL Learning Models Toward Speaking Ability Viewd from Students Motivation. Proceeding International Conference on Intellectuals'Global Responsibility (ASSEHR). Vol. 125, 75-79.

Darmuki, A., Andayani, Joko Nurkamto, Kundharu Saddhono. (2017). Evaluating InformationProcessing-Based Learning Cooperative Model on Speaking Skill Course. Journal of Language Teaching and Reasearch. 8(1) pp. 44-51.

Darmuki, A., Andayani, Joko Nurkamto, Kundharu Saddhono. (2018). The Development and Evaluation of Speaking Learning Model by Cooperative Approach. International Journal of Instruction. 11(2), 115-128.

Darmuki, A., Ahmad Hariyadi, Nur Alfin Hidayati. (2020). Peningkatan Minat dan Hasil Belajar Keterampilan Berbicara Menggunakan Metode Mind Map pada Mahasiswa Kelas IA PBSI IKIP PGRI Bojonegoro Tahun Akademik 2019/2020. Kredo.

Eliyawati, Cucu. 2005. Pemilihan \& Pengembangan Sumber Belajar untuk Anak Usia Dini. Jakarta: Pendidikan Tinggi Direktorat Pembinaan Pendidikan Tenaga Kependidikan dan Ketenagaan Perguruan Tinggi.

Gustama. (2004). Bahan Pelatihan Lebih Jaub Tentang Sentra dan Lingkaran. Jakarta: Direktorat Pendididkan Anak Usia Dini.

Irsyadiansyah, A. (2020). Perancangan Meja Dan Kursi Sebagai Pengenalan Bentuk. Geometri Dan Warna Untuk Anak Usia 4-6 Tahun (Doctoral dissertation, Universitas Mercu Buana Jakarta).

Montolalu, dkk. (2008). Bermain dan Permainan Anak. Jakarta: Universitas Terbuka.

Pratiwi, W. (2017). Konsep bermain pada anak usia dini. TADBIR: Jumal Manajemen Pendidikan Islam, $5(2), 106-117$.

Saleh, Martini \& Wismiarti. (2010). Sentra Balok (Panduan Pendidikan Sentra Untuk PAUD). Jakarta: Pustaka Al-falah.

Shobary, M. N., Riana, D., \& Sanjaya, R. (2014). Aplikasi Animasi Interaktif Pencampuran Tiga Warna Primer dan Pengenalan Bentuk Geometri pada PAUD Al-Muslimun. Jurnal Informatika, 1(2).

Sriningsih, Nining. (2009). Pembelajaran Matematika Terpadu untuk Anak Usia Dini. Bandung: Pustaka Sebelas.

Sugiyono. (2011). Metode Penelitian Pendidikan (Pendekatan Kuantitatif, Kualitatif, dan R \& D). Bandung: CV. Alfabeta.

Sugiyono. (2013). Metode Penelitian Pendidikan. Bandung: CV. Alfabeta.

Sikhah, (2018) Menumbubkan Kecerdasan Anak Melalui Permainan Balok (online) https://anggunpaud.kemdikbud.go.id/berita/index/20180906204726/Menumbuhkan-

Kecerdasan-Anak-Melalui-Permainan-Balok/, diakses pada tanggal 15 April 2021 